\title{
A Phase II/III, randomized, double-masked, vehicle-controlled, dose-ranging study of the safety and efficacy of OTX-IOI in the treatment of dry eye disease [Corrigendum]
}

Tauber J, Schechter BA, Bacharach J, et al. Clin Ophthalmol. 2018;12:1921-1929.

On page 1927, "Safety and tolerability assessments" section, third paragraph, first sentence should read from "Fifteen subjects exited the study due to AEs: 5 subjects (3.3\%) in the
OTX-101 $0.09 \%$ group, 4 subjects (2.6\%) in the OTX-101 $0.09 \%$ group, and 6 subjects (3.9\%) in the vehicle group." to "Fifteen subjects exited the study due to AEs: 5 subjects (3.3\%) in the OTX-101 $0.09 \%$ group, 4 subjects $(2.6 \%)$ in the OTX-101 $0.05 \%$ group, and 6 subjects $(3.9 \%)$ in the vehicle group."
Clinical Ophthalmology

\section{Publish your work in this journal}

Clinical Ophthalmology is an international, peer-reviewed journal covering all subspecialties within ophthalmology. Key topics include: Optometry; Visual science; Pharmacology and drug therapy in eye diseases; Basic Sciences; Primary and Secondary eye care; Patient Safety and Quality of Care Improvements. This journal is indexed on

\section{Dovepress}

PubMed Central and CAS, and is the official journal of The Society of Clinical Ophthalmology (SCO). The manuscript management system is completely online and includes a very quick and fair peer-review system, which is all easy to use. Visit http://www.dovepress.com/ testimonials.php to read real quotes from published authors. 